\title{
The Analysis Potentials and Sustainablity Development of Agro-Ecotourism in Palopo, South Sulawesi
}

\author{
Rahmat $^{1 *}$, Abdul Hakim ${ }^{2}$, Harsuko Riniwati ${ }^{3}$, Hasnidar Yasin ${ }^{4}$ \\ ${ }^{1}$ Doctoral Program of Environmental Science, Postgraduate School, University of Brawijaya, Indonesia \\ ${ }^{2}$ Department of Public Administrative Science, Faculty of Administrative Science, University of Brawijaya, Indonesia \\ ${ }^{3}$ Department of Fishery Social Economics (Fishery Agribusiness), Faculty of Fisheries and Marine Science, \\ University of Brawijaya, Indonesia \\ ${ }^{4}$ Faculty of Fisheries and Marine, Indonesian Islamic University, Makassar, Indonesia
}

\begin{abstract}
Latuppa Area in Palopo is located in the northern part of South Sulawesi Province. It has some potential cultural and natural tourism spots to develop using the concept of agro-ecotourism. Sustainable tourism is considered as a step to manage all resources socially and economically. It can be done by preserving the cultural integrity, basic ecological processes, biological diversity, and other life support elements. This study was aimed to determine the potential attraction and to analyze the sustainability status and to construct the model of Latuppa agro-ecotourism development in Palopo, South Sulawesi. The model of sustainable agro-ecotourism development in Palopo, South Sulawesi Province, was conducted with qualitative and quantitative research method, using MDS and analysis of SWOT. The result of the index value of sustainability from five dimensions is 59.39. It means that by paying attention on the dimension aspects of ecology, economy, socio-cultural, technology, and institution at Latuppa, agro-ecotourism area can support the agroecotourism. The results of SWOT analysis that can be applied in the analysis of the strategy for the sustainable Latuppa agro-ecotourism development are as follows. The strategies are creatinga new tourist attraction to attract the tourists, educating the local community in terms of tourism management, developing tourism products, and promoting tourism objects.
\end{abstract}

Keywords: agro-ecotourism, development, ecology, sustainablity.

\section{INTRODUCTION}

Tourism cannot be separated from conservation efforts, local economic empowerment, and support on higher respect for cultural differences. One of the efforts on optimum local resources utilization is by developing tourism using the concept of ecotourism [1].

Ecotourism is a natural tourism activity that is responsible for preserving the originality and sustainability of the environment and raising the local community's prosperity. Ecotourism is a tourism concept that is close to the principle of conservation. Even in development, ecotourism also uses a conservation strategy. Thus, ecotourism is very suitable and effective in preserving the integrity and originality of the ecosystem in a natural area [2,3].

Ecotourism is everything that exists in an area that can be developed into a tourist attraction. The potential divided into two, namely cultural potential and natural potential. Cultural potential includes potential that grows and develops in the community, such as customs, livelihoods and

\footnotetext{
*Correspondence address:

Rahmat

E-mail : rahmatmb1565@gmail.com

Address : Postgraduate School, University of Brawijaya, Mayjen Haryono 169, Malang 65145.
}

arts. Meanwhile, the natural potential is in the form of physical, geographical potential of nature, including the type of flora and fauna in an area. Ecotourism is an environmentally responsible tourism activity, contributing positively to environmental conservation and paying attention to the welfare of local communities [4].

Sustainable development, which is a step to be able to harmonize, integrate, and generalize the environmental, economic, and social aspects of culture. Sustainable development has a normative value and has principles in it. This principle is referred to as the three pillars of resilience (The Three E's of Sustainability), which consists of economic growth, environmental sustainability, and social equality (equity). The sustainability of the economic system must be able to produce goods and services that meet basic needs that will support economic growth, but must be integrated with the existence of environmental ecosystems $[1,5]$.

In this study, the discussion of sustainable tourism based on the understanding that ecotourism is a tourist activity that packaged professionally, trained, and contains elements of education. Ecotourism act as one of the economic sectors/businesses that considers cultural heritage, participation, and welfare of 
local residents and conservation efforts of natural and environmental resources [6]. The components of ecotourism are as follows: contributing to biodiversity conservation; supporting the well-being of local communities; increasing learning experiences; involving responsible actions from tourists and tourism; provided to small business groups; using nonrenewable resources as low as possible; emphasizing local community participation in both ownership and business opportunities, especially for rural communities $[2,3,7]$.

Environmental susutainability is crucial issues in tourism planning and and development. There are numerous factors contributes to the sustainability of tourism, including the role of technology. Environmental sustainability of the Mayangan Fish Port (MFP) in Probolinggo showed that technology is the main dimension that supports the sustainability of the MFP. The type of traditional technology used is sustainable for ecology. Guidance by the government is needed for community and management to face the need for a more modern development and product diversification [8].

Palopo City is located in the northern part of South Sulawesi province, $326 \mathrm{~km}$ from Makassar City. It also has several potential cultural and natural tourism locations to be developed, such as Langkanae Traditional House, Batara Guru Museum, Bukit Sampoddo, Labombo Beach, Songka Beach, and Latuppa Tourism Village. The tourism potential is feasible to be developed by the local government, in this case, the Culture and Tourism Office as a sector leader, by arranging the tourism sectors owned. But in reality, some of the existing tourism potentials have not been fully utilized by the local government, in this case, the Culture and Tourism Service.

Latuppa Tourism Village is a tourism object which located in Palopo, the northern part of South Sulawesi Province. The weakness of this tourism object is the environmental condition, facilities, and infrastructure, which is less supportive to attract visitors. Therefore, thorough attention from Palopo District Government is needed to support the development of the Latuppa Tourism AreaMany of the tourism potentials were neglected and not managed properly, such as Songka Beach natural attractions that currently do not have activities, facilities, and infrastructure to support tourism objects. Another natural attraction with poor management isLangkane Traditional Houses. The cleanliness of the surrounding environment is poorly maintained, even though traditional houses it is often used as a place for cultural activities and other traditional activities, and access to Latuppa village tourism objects is still inadequate [9].

Tourism is considered as one of the alternatives to raise the district's income. This potential optimization is based on the idea that tourism is a sector that emphasizes providing service and optimizing the tourism area to be ecotourism. Because ecotourism always keeps the quality, integrity, and originality of nature and culture, a development model is needed to develop Latuppa agro-ecotourism.

The previous studies have shown phenomena where Latuppa agro-ecotourism has not involved the local community or the stakeholders as the ecotourism theory suggests. It is because people have not realized the benefits of agro-ecotourism. As an empirical fact, Coyle-Shapiro'sstudy showed the not-strongparticipation of the local community in developing Latuppa agro-ecotourism in Paloppo [9]. This study, as a further study, aimed to analyze the sustainability status of Latuppa agroecotourism, which is seen from the dimension of ecology, economy, socio-cultural, technology, and institution and also constructing the model of Latuppa agro-ecotourism development in Palopo, South Sulawesi.

\section{RESEARCH METHODS}

This study on the model of sustainable agroecotourism development in Palopo, South Sulawesi Province, was conducted with qualitative and quantitative research methods. The study used the Multi Dimension Scale (MDS) to know the level of sustainability in and analysis of SWOT.

\section{Study Area}

The research location was conducted in the Latuppa Agrotourism Area of Palopo City, Mungkajang District (Fig. 1). Palopo City is one of the administrative city areas in the area of South Sulawesi Province with an area of $258.17 \mathrm{~km}^{2}$ with nine sub-district administrative areas covering the District of South Wara, Sendana District, Wara District, Wara Timur District, Mungkajang District, District North Wara, Bara District, Telluwanua District and West Wara District with a total of 48 villages. The area of the Subdistrict in Palopo City consists of nine Subdistricts, each sub-district with a diverse composition of the village. 


\section{Data Collection}

The techniques of data collection conducted in this study were:

a) Observation; Data were collected through direct observations on research respondents. Observation and data collection is carried out to tourists visiting the Latuppa agro-tourism area as well as to tourism managers in each tourist destination.

b) Questionnaire; Data were collected by giving respondents some structured written questions about their answers to the various variables examined in this study. A total of 30 respondents were tourists visiting several destinations in the Latuppa agro-tourism area.

c) Interviews; Data were collected by doing indepth questions and answers with respondents to get more accurate and complete data with further explanation of the questionnaire. In-depth interviews conducted with tourism managers, the head of a tourism management group in the Latuppa agrotourism area.

\section{Data Analysis}

MDS

Data from all of the collection methods were analyzed using multidimensional scaling (MDS), which includes four dimensions, 1) ecological, 2) economic, 3) socio-culture, technology, and 4) institutional dimension. These dimensions will be on the analysis of the sustainability level through the study. Giving a score for each attribute can describe the sustainability conditions of each dimension, whether good or bad.

\section{RAPFISH}

The questionnaire that has been obtained from respondents then tabulated into RAPFISH software. It was to measure the value of each dimension of sustainability and overall sustainability [10].

\section{SWOT}

SWOT analysis used to determine the regional development strategy Latuppa Agrotourism. The SWOT analysis is used to determine the development strategy of the Latuppa Agrotourism area. SWOT (Strength, Weaknesses, Opportunities, Threat) analysis is a systematic identification of various factors to formulate a strategy. SWOT analysis is an analysis of the internal and external conditions of an organization, which then used as a reference basis in designing work strategies and programs [11].
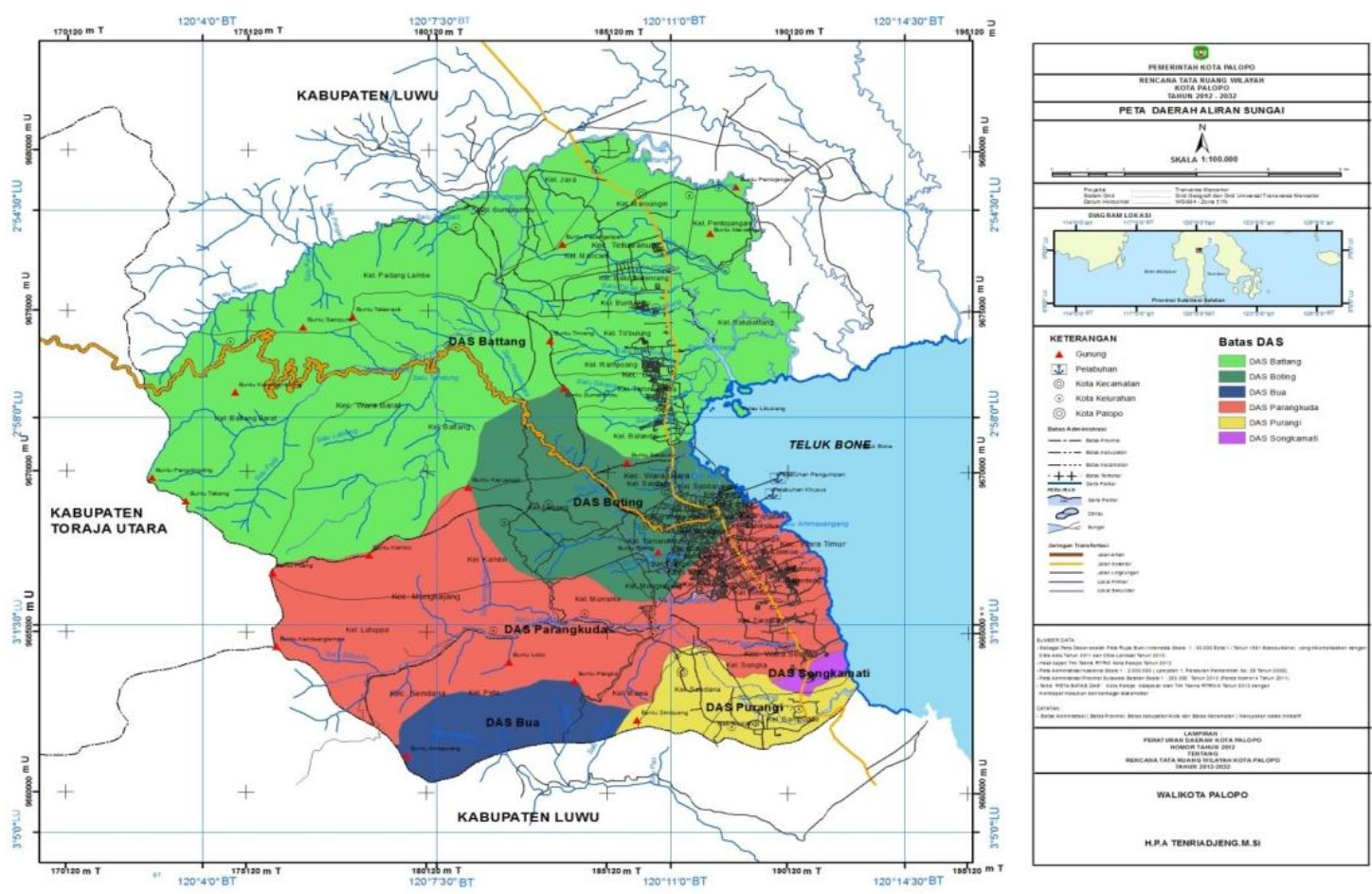

Figure 1. Map of Research Location in Latuppa, Palopo 


\section{RESULT AND DISCUSSION}

\section{Agrotourism of Latuppa in Palopo}

In Paloppo, there are many natural tourism spots. One of them is the agrotourism spot, which located in Latuppa, about $5 \mathrm{~km}$ from the central part of Palopo City. Latuppaagrotourism area is at an elevation of 200 masl and famous as fruits and agricultural products producers.

The result of the study had found the potentials of Latuppa agrotourism, where some of them are heritage tourism, water tourism, culinary tourism, and nature tourism.Nature tourism consists of marine tourism and mountain tourism. Many fruit plantations can be used as edutourism.Area with abundance fruit orchards has potentiality to be developed as agrotourism area [12].

Latuppa Agrotourism is more popular with waterpark spots, where it always crowded with visitors on weekends, school holidays, or major religious holidays. At the agrotourism, there are five swimming pools for adults and children with different depths. The swimming pools can accommodate up to 500 visitors.

There are various potentials obtained from the study, starting from natural resources, good accessibility, and human resource. Surely, the local government's roles to synergize with the local community are important to develop agroecotourism in Latuppa to increase the number of visitors or tourists.

\section{Analysis of Sustainability}

The analysis of agro-ecotourism sustainability in Lattupa performed with the method of MDS assisted by RAPFISH. In this analysis, five dimensions were used to measure Latuppa agroecotourism sustainability: ecology, economy, socio-culture, technology, and institution.

\section{Dimension of Ecology}

From the aspect of ecology, the condition in Latuppa agro-ecotourism area is adequate to support agro-ecotourism sustainability. The result of the study showed that the ecological attribute which very much influenced the sustainability of this dimension was fresh air. There were garbage landfills and effortson environment conservation at the agroecotourism area.

On the ecological dimension, the highest value found in the fresh air attribute (Fig. 2). It is because the condition of the forest in the agrotourism area is still maintained. Meanwhile, the lowest attribute value is the Latuppa area maintained by the environment and cleanliness.It is due to a lack of awareness of the waste carried.

To ensure the sustainability of the ecological aspects, it should be established that members of the institution are environmentalists. Therefore, their passion fused with the environment and network, with both environmentalists and funding activity has been formed. As the previous research [13], to guarantee institutional sustainability, it requires reliable actors and institutional networks.

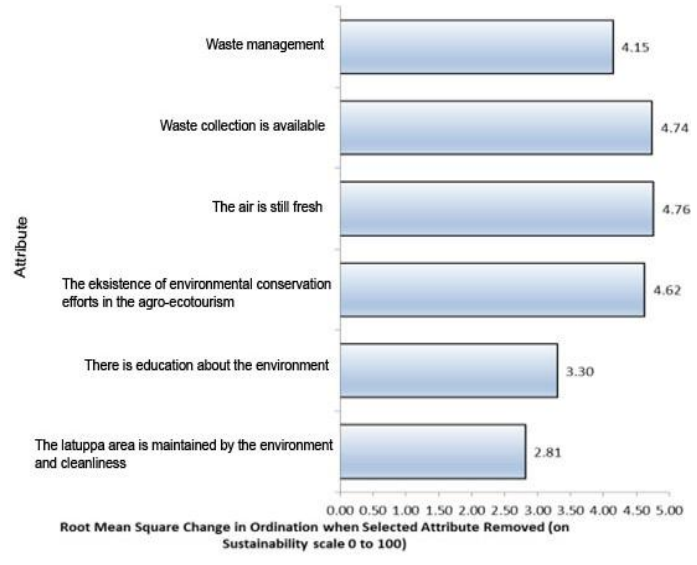

Figure 2. TheSensitivity of Ecological DimensionAttribute

\section{Dimension of Economy}

In terms of economic dimension, agroecotourism in Latuppa Area has a fair grade in sustainability. However, the community's creativity in management needs to be improved so that the local community's economy and prosperity also improved.

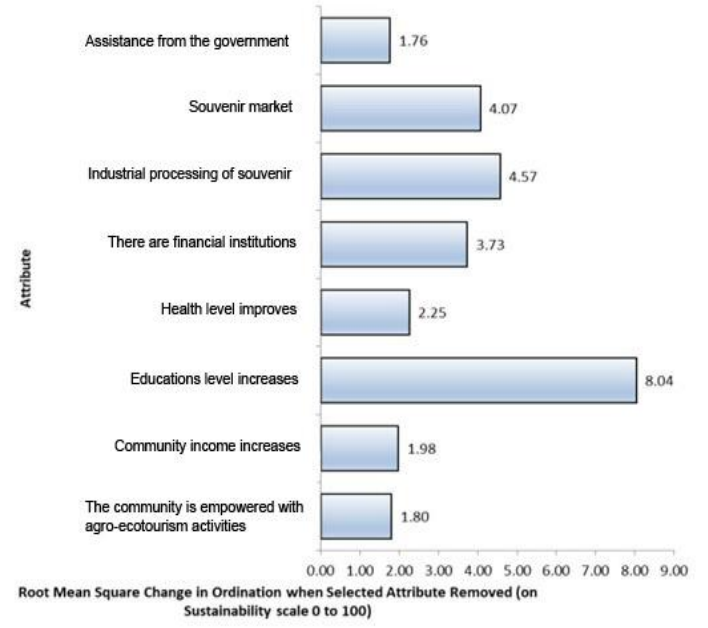

Figure 3. The Sensitivity of Economic Dimension Attribute

The attributes with high sensitivity towards the economical dimension are education level and availability of the souvenir industry (Fig. 3). Those attributes have the biggest leverage value. 
With Latuppa agro-ecotourism management, the community's education level improves, and it is followed by the emerging of some Latuppa specialties gift/souvenir centers. It can be improved more so that the local community's economy around Latuppaalso improves.

In the economic dimension, the highest attribute value is the education level increases. It is due to an increase in people's income so that the ability to continue their education improves.

\section{Dimension of Socio-Culture}

The result of the MDS analysis on the sustainability status is fair. The result shows that the attribute that influences the sustainability ofthe socio-cultural dimension significantly is the conflict potential because this attribute has the biggest leverage value (Fig. 4).

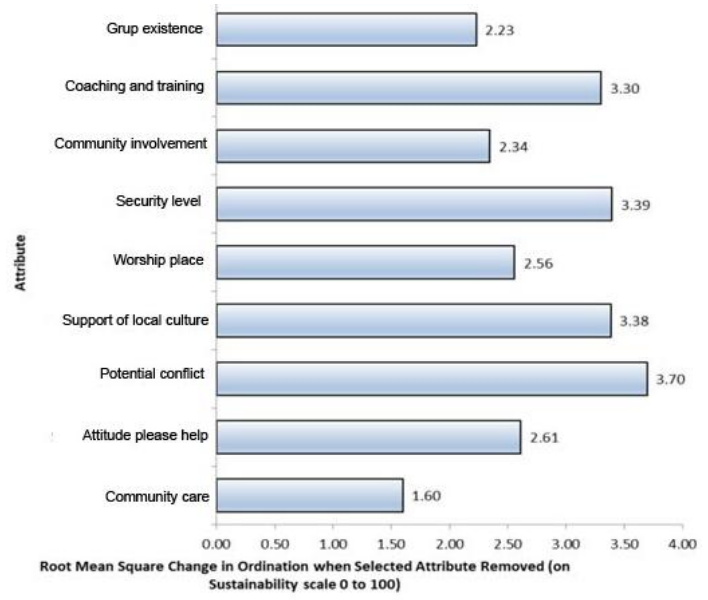

Figure 4. The Sensitivity of Socio-Culture Dimension Attribute

On the socio-cultural dimension, the highest attribute value is the level of potential conflict.It is due to business competition in the process of tourism activities. With the existence of tourism activities, it is clear that there will be competition for tourism businesses both from the managers and local communities so that there must be government intervention in its resolution.

\section{Dimension of Technology}

The result of MDS analysis on the sustainability of the technological dimension shows that Latuppa Tourism Area is fairly sustainable. The attribute which influences significantly is the availability of health facility and information. The lowest is promotion, facility, and infrastructure. It is because telecommunication network and the transportation, which can support tourism activities, have not been available at some areas of Latuppa agro-ecotourism.
On the technological dimension, the highest attribute value is medical devices (Fig. 5). The availability of facilities and infrastructure that support health in the agro-tourism area is also increasing because tourism activities are sometimes risky to health.

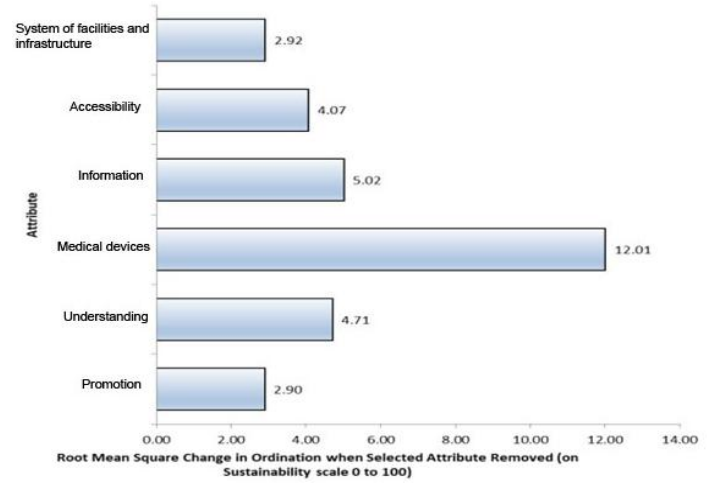

Figure 5. The Sensitivity of Technological Dimension Attribute

\section{Dimension of Institution}

The result of MDS analysis on the sustainability status of institutional dimension is fair. It is because the local community in the area has established a management group in each destination in Latuppa agro-ecotourism so that the management and implementation run well. On the institutional dimension, the highest attribute value is the transparency of funds (Fig. 6). It is due to the level of trust in good institutions and management that promotes mutual cooperation.

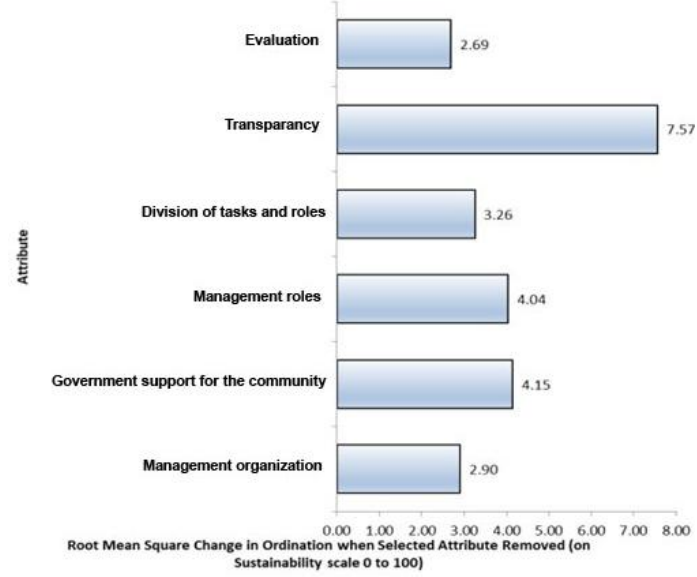

Figure 6. The Sensitivity of Institutional Dimension Attribute

To maintain the sustainability of the institution dimension, they must form a network with environmentalists, both in activities and funding. As a result of previous research [13], to 
ensure institutional sustainability, they in need of reliable actors and institutional networks.

Pitcher and Preikshot [10] categorized the measurement result ofthe sustainability of each dimension attributes. They mapped into two reference points, which are bad-down points and good-up points. The grouping or the marking of the sustainability status categorized into fourand presented in Table 1.

Table 1. Sustainability Status Category

\begin{tabular}{lcc}
\hline $\begin{array}{c}\text { Index of } \\
\text { Dimension Value }\end{array}$ & Category & Information \\
\hline $00.00-24.99$ & Bad & Not Sustainable \\
$25.00-49.99$ & Less & Less Sustainable \\
$50.00-74.99$ & Fair & Fairly Sustainable \\
$75.00-100.00$ & Good & Sustainable \\
\hline
\end{tabular}

Source: Pitcher and Preikshot [10].

On average, the index value of the sustainability of five dimensions is $\mathbf{5 9 . 3 9}$ (Fig. 7). This number shows that paying attention to the dimension aspects of ecology, economy, sociocultural, technology, and institution at Latuppa agro-ecotourism area can support the agroecotourism.

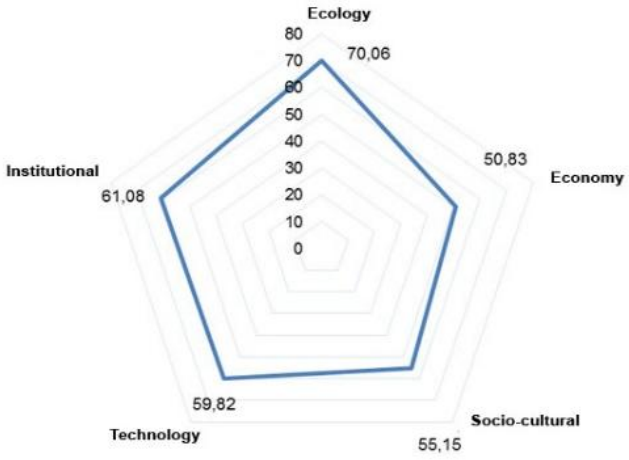

Figure 7. Sustainability Status Chart with RAPFISH

Based on RAPFISH analysis, if the diagramindex is getting out of the line or approaching 100 , the sustainability status is good. On the contrary, if the index is going inside the line or approaching 0 , the sustainability status is getting worse. From those five dimensions, the worst sustainability index is on the dimension of the economy. Therefore, there must be efforts to improve the economic sector to improve sustainability status and make it balanced. The most sustainable dimension is ecology.

\section{Latuppa Agro-Ecotourism Development Strategy}

In a study conducted by Senna [9], the potential of tourism in Latuppa is feasible to be developed by the regional government, in this case, the Culture and Tourism Service as a sector leader, by managing the tourism sector that is
owned.But in reality, some of the existing tourism potentials have not been fully utilized by the local government, in this case, the Culture and Tourism Service. Many tourism potentials are neglected and not well managed.Such as Songka Beach natural attractions that currently do not have activities, facilities, and infrastructure to support tourism objects. Another natural attraction, Langkane Traditional Houses, has poor environmental cleanliness. Although traditional houses often used as a place for cultural and other traditional activities, access to Latuppa village tourism objects is still inadequate.

The results of SWOT analysis with strategy that can be applied in the sustainable Latuppa agro-ecotourism development are as follows: create a new tourist attraction to attract tourists; educating the local community in terms of tourism management; developing tourism products and promoting tourism objects; involving the local community in managing tourism, working cooperatively with related parties; forming kelompok sadar wisata (the tourism awareness group).The model formulation of sustainable Latuppa agroecotourism development described below.

1. Developing tourism products and promoting tourism objects. Latuppa agricultural products need to be developed, so that they can attract the community/visitors to buy and give advantage for Latuppa agro-ecotourism area in Palopo.

2. Making an attractive tourism area for visitors. Latuppa tourism area has very great potential. That is why a new tourism concept combined with the potency in Latuppa agroecotourism area is needed to attract the visitors.

3. Educating the local community in terms of tourism area management. Local government work cooperatively with local community conduct a workshop to develop Latuppa agroecotourism area, in terms of tourism product development (economy), developing village cooperative system, developing sustainable tourism, conservating the protected forests; river basin; waterfall area (the Department of Environment and Forestry), and promoting Latuppa tourism area by involving the local youth.

4. The Involvement of Community in Managing Tourism. All communities of Latuppaneed to participate in supporting the development of Latuppa agro-ecotourism area, in terms of 
agricultural product improvement, tourism preservation, facilities, and infrastructure to support Latuppa agro-ecotourism.

5. Work cooperatively with any related parties. In developing a tourism area, it is important to work cooperatively with any parties in developing Latuppa agro-ecotourism areas such as academics, non-governmental organizations, and others.

6. Forming kelompok sadar wisata (the tourism awareness group). This group will be active in developing Latuppa agro-ecotourism areas such as area preservation, activities control, evaluation, and other related activities.

Dimensional analysis in sustainable development modified with SWOT analysis gives important information for researchers and organizations concerned with the environment. As stated by a previous study [14], there is a growing awareness by researchers and practitioners of organizations that are responsible in the ecological field. The management of an organization shows that it is important to develop ecological, economic, and social sustainability. Technology-based management information systems can help organizations develop ecological, economic and social sustainability into eco-efficiency, eco-equity, and eco-effectiveness.

To maintain the balance of the utilization of the general environment from the aspects of the economy, ecology, socio-culture, institutions, and technology, it needs to be carried out by crosssectoral institutions (community, private, government). Thus the cross-sectoral role in ensuring the sustainability of all dimensions is very important. Of course, it must be maintained so that the commitment is the same to avoid increase conflict. Cross-sectoral institutions create policies for protecting ecosystems [15].

\section{CONCLUSION}

There are various potentials obtained from the study, starting from a natural resource, good accessibility, and human resource. The local government's roles to synergize with the local community are important to develop agroecotourism in Latuppa to increase the number of visitors or tourists.

The models needed to develop in developing the agro-ecotourism in Latuppa are: Creating a new tourist attraction to attract tourist, educating the local community in terms of tourism management, developing tourism products and promoting tourism objects, involving the local community in managing tourism and forming kelompok sadar wisata (the tourism awareness group). Tourism objects in Latuppa can compete with other tourism objects if all power and opportunities are improved, weakness is minimized, threats are prevented, and an exact development strategy is applied.

\section{Acknowledgment}

We thank the community of Palopo City, especially Latuppa community who supported us in this research.

\section{REFERENCES}

[1] Hakim, L., M. Soemarno, and S. K. Hong. 2012. Challenges for conserving biodiversity and developing sustainable island tourism in North Sulawesi Province, Indonesia. Journal of Ecology and Environment 35(2), 61-71.

[2] Hakim, L. 2004. Dasar-dasar ekowisata. Bayumedia. Malang.

[3] Fennell, D. A. 2014. Ecotourism. Routledge. New York.

[4] Suarka, F. M. 2010. Strategi pengembangan ekowisata di Desa Jehem Kecamatan Tembuku Kabupaten Bangli. Master Thesis. Udayana University. Denpasar.

[5] Parmawati, R. 2018. Ecology, Economy, Equity: sebuah upaya penyeimbangan ekologi dan ekonomi. Universitas Brawijaya Press. Malang.

[6] Nugroho, I. 2011. Ekowisata dan pembangunan berkelanjutan. Pustaka Pelajar. Yogyakarta.

[7] Wood, M. E. 2002. Ecotourism: principles, practices and policies for sustainability. Division of Technology, Industry and Economics, United Nations Environment Programme (UNEP). France.

[8] Parmawati, R. and A. S. Kurnianto. 2018. Features, innovation, and environmental sustainability of Mayangan Fish Port, Probolinggo, Indonesia: an analysis of MDS. IOP Conference Series: Earth and Environmental Science 239. Available at: https://iopscience.iop.org/article/10.1088/ 1755-1315/239/1/012037.

[9] Senna, A. M. 2014. Analisis potensi pariwisata dalam pelaksanaan Otonomi Daerah di Kota Palopo. Bachelor Thesis. Department of Political Science and Governmental Science, Faculty of Social and Political Science, Hasanuddin University. Makassar. 
[10] Pitcher, T. J. and D. B. Preikshot. 2001. RAPFISH: a rapid appraisal technique to evaluate the sustainability status of fisheries. Fisheries Research 49(3), 20872852.

[11] Rangkuti, F. 2004. Analisis SWOT teknik membedah kasus bisnis, reorientasi konsep perencanaan strategis untuk menghadapi abad 21. PT. Gramedia Pustaka Utama. Jakarta.

[12] Tanjungsari, A., A. F. Cholis, C. Y. Riung, L. E. Rokani, and L. Hakim. 2016. Analisis Potensi Agrowisata Buah di Wana Wisata Rawa Bayu, Desa Bayu, Kecamatan Songgon, Kabupaten Banyuwangi. Biotropika: Journal of Tropical Biology, 4(3), 67-72.

[13] Jennings, P. D. and P. A. Zandbergen. 1995. Ecologically sustainable organizations: An institutional approach. Academy of Management Review 20(4), 1015-1052.

[14] Chen, A. J.W., M. C. Boudreau, and R. T. Watson. 2008. Information systems and ecological sustainability. Journal of Systems and Information Technology 10(3), 186201.

[15] Carter, H. N., S. W. Schmidt, and A. C. Hirons. 2015. An international assessment of mangrove management: incorporation in integrated coastal zone management. Diversity7, 74-104. 